\title{
ENVIRONMENTALISM AND FOREST RIGHTS OF TRIBALS IN DAKSHINA KANNADA, UDUPI AND UTTARA KANNADA DISTRICTS OF KARNATAKA
}

\author{
M. K. Hareesha* \& Midatala Rani**
}

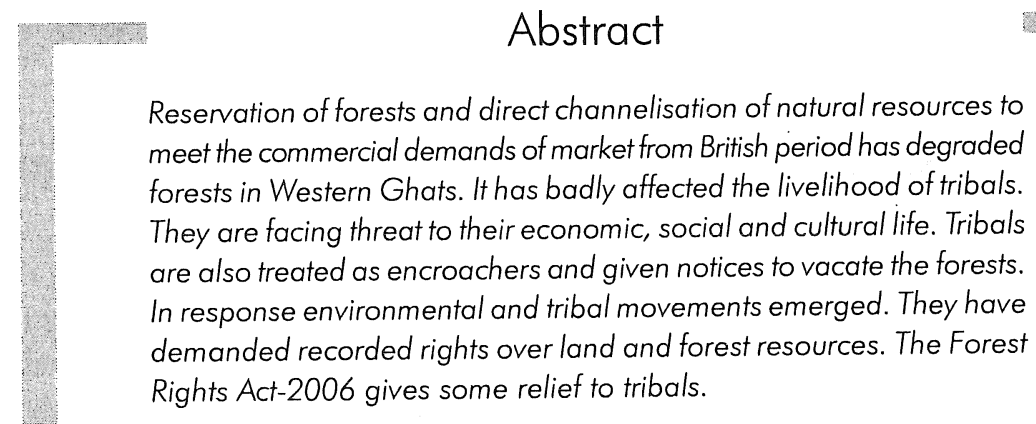

* Senior Lecturer in Political Science, Government First Grade College, Mudigere, Chikkamagalur district, Karnataka-577132.

* Reader, Department of Studies in Political Science, Mysore University, Mysore. 


\section{Introduction}

Forest conflicts and issue of forest rights of tribals and local people arised when British conquered coastal districts in 1779 from Tippu Sultan. British denied traditional forest rights of tribals and local people and reserved forests. Forest resources were exploited largely to serve the military and commercial needs of British Empire.

Traditionally, forests were under community ownership and the trees were not to be cut without having obtained permission from the headman of the village. The forests were also treated as property of Village God. But the British decided to assume ownership of forests. Through Indian Forest Acts of 1865 and 1878, the British acquired a monopoly rights over forests by converting them into 'reserved forests'. They banned tribals and local people from entry into forests, collecting green manure, dry leaf, firewood, fiber, fruits, honey etc. They also banned shifting cultivation of tribals. These encroachments conflicted seriously with the interests of and tribals local people.

In the post-colonial period, state planned industrialization created more intensive and exclusive demands for raw materials for forest based industry. Working plans were formulated for 'scientific development' of forests. Common property resources like grazing lands are also planted with eucalyptus and teak to meet the growing demands of forest based industries. These new demands posed new threat to the survival of tribals and local village communities through ecological degradation. The post-colonial period has thus been associated with a new kind of forest struggle based on conservation rather than consumption of forest resources.

\section{Impact of Reservation of Forests and Deforestation on Tribals}

Tribal societies were self sufficient till the advent of colonism. Their agricultural practices, primarily shifting cultivation was eco-friendly and self-sufficient. The ban of shifting cultivation in both colonial and post-colonial forest administration destabilized the livelihood of tribals. Monopoly control over forests by the state, commercial forestry, and timber trade also destabilized livelihood base of tribals. The exclusion of local rights and the consequent destruction of the local livelihood systems are the most dramatic consequence of these developments.

Tribals are living in and around the forests since the beginning of civilizations. They had depended on forest resources for their daily livelihood and were self-sufficient. Traditionally, they had been extracted forest products like honey, fruits, food, firewood, fiber, grass meat, fish and small timber for their survival. However these activities 
were restricted by traditions and customs. But commercialization of forest products started with the British rule. Tribals were expelled from the forests or barred from entry into the forests. They are treated as 'encroachers'.

In Dakshina Kannada and Udupi districts, tribals like 'Malekudiyas' and 'Goudlus' in Kudremukh National Park facing the threat of expulsion. In Uttara Kannada district, tribals like 'Gavlis' and 'Siddis' are victims of deforestation and environmental degradation. The forests of Uttara Kannada harbor over a thousand families of a group of forest dwelling pastorals called 'Dhangar Gavalis'. These families have in average ten or more cattle. They are grazing forest areas. The Forest Department has been trying to move them outside the forest area. But Gavlis refused to go out of the forests and continuing in the forest with the fear of expulsion.

\section{Kudremukh National Park and Encroachment issue.}

The Government of Karnataka has issued a notification under Wildlife Protection Act-1972 to declare 1.39 lakh acres out of 1.49 lakh acres of reserved forest as Kudremukh National Park in 1987. As per the notification, five Reserve Forests including (1) Andar Reserve Forest, (2) Naravi Reserve Forest, (3) Narasimhaparvatha Reserve Forest, (4) Tungabhadra Reserve Forest, and (5) South Bhadra Reserve Forest have been notified as the area constituting Kudremukh National Park.

In 1998 the Government of Karnataka started to implement the order strictly after the Supreme Court order to vacate the people who have encroached this place. Encroachment of this forest area is a very complex issue, because big and small farmers, tribals and others encroached the forest area for cultivation. It is alleged that big farmers encroached the forest area to extend their estates. But small farmers and tribals have no knowledge of forest acts and reservation of forests, cultivated some portions of the National park and are living there from many years. However, all encroachers are given notices to vacate forest area. This has created a conflict against Forest Department from tribals and farmers.

Encroachment issue has created mixed response. Conservationist environmentalists welcome the order of the Supreme Court, while Gandhian and Marxisst environmentalists argue that evacuation of tribals will not help in conservation of forests. Experience shows that existence of tribals in the forest area is helpful in conservation of forests. Tribals do not destroy forest because they have deep attachment with forest. They collect only minor forest produce and protect forest from poachers, smuggles etc. It is also argued that tribals culture, identity and lifestyles are identified with the forest. 
Encroachment in Kudremukh National Park (Estimated)

\begin{tabular}{|l|l|r|r|r|}
\hline \multicolumn{1}{|c|}{ District } & \multicolumn{1}{|c|}{ Taluk } & $\begin{array}{c}\text { No. of } \\
\text { Villages }\end{array}$ & $\begin{array}{c}\text { No. of } \\
\text { Tribal } \\
\text { families }\end{array}$ & $\begin{array}{c}\text { Total } \\
\text { families }\end{array}$ \\
\hline Udupi & Karkala & 4 & 100 & 175 \\
Dakshina Kannada & Belthangadi & 11 & 125 & 253 \\
Chikkamagalur & Shringeri & 16 & 800 & 1000 \\
& Koppa & 3 & 150 & 250 \\
& Mudigere & 3 & 250 & 350 \\
\hline \multicolumn{1}{|c|}{ Total } & 5 & 37 & 1425 & 2028 \\
\hline
\end{tabular}

Source : District Forest Department office, Dakshina Kannada district, Manglore.

Tribals and small farmers strongly opposed the declaration of Kudremukh National Park. With the help of NGO's, they formed 'Kudremukh Rastriya Udyana Virodhi Okkoota' to oppose the National Park and evacuation of tribals and small farmers from forest. Tribals are struggling for their forest rights from beginning of modernization. To recognize the rights of tribals the Forest Rights Act-2006 is passed by the parliament. The Forest Department is evacuating the tribals and farmers amid implementation of Forest Rights Act-2006. This is creating confusion and distress among tribals and small farmers.

\section{Tribals and Land Question}

Exploitation of natural resources in forests to fulfill the raw material demand of market economy degraded forests in Western Ghats. Dams, extraction of timber and firewood, mining and commercial exploitation of minor forest resources destroyed thousands of hectares of forests. When forest resources dwindled, it badly affected the livelihood of the tribals living in and around the forests. Thus, competition and conflicts over natural resources started between tribals and market economy. Instead of market economy, tribals are treated as responsible for degradation of forests.

With the forest resources are dwindled, the Government undertook several measures to improve forests in the name of eco-development. Afforestation programmes are started by planting commercially valuable teak and eucalyptus. To 'improve' tribals life, programmes are formulated to shift them from forest and resettle in outside the forests. But tribals are reluctant to go outside the forest and demanded land rights in the forests. 
Fights for the regulation of land holdings in forests have occurred for many decades. Gandhian and Left movements believe that inhabitants living inside the forest should have recorded rights and should be the owners of their own 'pattas'. The confrontation between these movements and Forest Department intensified in the wake of the may 2002 Supreme Court order for the eviction of all encroachers from the forests within the next six months. The question of who is an 'encroacher' and issues related to the ownership of land within forests has created a major controversy. State monopoly ownership of forests has been a colonial legacy and also the major bone of contention between grassroots movements and the state. The Forest Department was formed in 1865 and coincided with the first Forest Act, which declared that hence forth the state would own all forest lands. Henceforth the Forest Department is to have arbitrary and exclusive control over these lands and develop its own police, courts and laws. The rights of the local people, most of them are tribals, are severely constricted and their control over the bio-resources of their area is minimal. Under Forest Acts, no local people and tribals are entitled to and, in most cases, they are to be evicted from forest areas as 'encroachers'.

The first post-colonial statement on forests, the National Forest Policy, 1952, supported the view that priorities of forest management must subordinate themselves to larger national goals, more specifically the industrialization of the nation.

'National needs' were in turn defined in terms of raising plantations for industrial uses. A big programme was introduced in the Third Five Year Plan to clear existing forests and to create mono-plantations for industry. Many of the varieties promoted for this purpose were commercially valuable species, like eucalyptus and teak. But Five Years Plans never mentioned the problem of reconciling tribals forest use with this form of production forestry. Instead, it was assumed that tribals would benefit indirectly through wage increase as they would form the main labour force of the Forest Department. It was thus hoped that the plantation programme would provide an alternative form of livelihood to tribals. But more than this, the significance of these developments lay in the way in which tribals were deprived of their productive assets and converted into daily wage laborers. However the forest was actively utilized for commercial and industrial purpose. Hence, tribals continuously struggled for land rights in forest. In Western Ghats, tribals under the banner of 'Vanavsi Kalyana Mahasbha' demanded land rights in forests.

In this context, the Forest (conservation) Act of 1980 is the most important milestone from the point of view of diversion of forest lands for agricultural and other purposes. The Act permits the regularization of pre 1980 encroachments, but stops the regularization of post-1980 encroachments. On the basis of Forest Act of 1980, the 1988 National Forest Policy outlined that 'regularization of encroachments' is 
not possible for post - 1980 encroachments. The Forest Department has issued guidelines to the state that pre-1980 encroachments are only to be regularized if the State Government's decision was taken before enactment of the 1980 Act. These measures were given a significant boost by the lobby of conventional environmentalists, who put up a writ petition in Supreme Court that challenged the regularization of forests encroachments in states. The Supreme Court ruled that the regularization of encroachments would be banned with effect from November 2001 in light of this petition unless allowed by the Supreme Court. This judgment formed the basis of the Forest Department's notification of May 2000 stating that all encroachments are ineligible for regularization since 1990 should be summarily evicted.

The Government refused to make a distinction between encroachments for commercial purpose and encroachment for livelihood. Hence, tribals fear that much of eviction process will concentrate on tribals who have no political clout to protect their interests. In Dakshina Kannada and Udupi districts about 428 families of 15 villages are considered as encroachers in Kudremukh National Park. Out of them about 225 families are tribals. Forest Department has issued notices to all the 428 families to evacuate from the forest. But tribals refused to evacuate from the forests and demanded the land rights. They succeeded in their struggle, when the Forest Rights Act-2006 is notified by the Government of India. It gives major relief to the tribals against threat to their survival.

\section{The Forest Rights Act-2006}

The Scheduled Tribes and Traditional Forest Dwellers (Recognition of Forest Rights) Act 2006 (FRA) is notified on January 8, 2008. This is the result of years long struggle of forest dwellers and tribals for forest rights. The FRA recognizes the forest rights of tribals. Tribals now can live and cultivate in forest for their survival. The Act recognizes the right of ownership access to collect, use and dispose of minor forest produce. The FRA has defined the term minor forest produce to include all non-timber forest of plant origin including bamboo, brushwood, stumps, cane, tussar, cocoons, honey, wax, lac, tendu or kendu leaves, medicinal plants and herbs, roots and tubers. Each family of Forest dwellers or tribals have the right up to four hectares of forests.

Environmental and Tribal Movements now are working to create awareness among the tribals and forest dwellers about the Forest Rights Act-2006. They are organizing awareness programmes in the forest areas. 


\section{Conclusion}

Tribal and environmental movements have welcomed the Forest Rights Act2006(FRA). Finally livelihood base of tribals is recognized. But the FRA is opposed by conservationalist environmentalists, forest bureaucracy, and paper and pulp industries. The opponents of the FRA have raised several objections. They include, the enactment of the FRA would endanger tiger population in the country; that the law would culminate in the irrational distribution of forest land to tribals; and that it would curtail drastically the supply of pulp for industry.

The introduction to the FRA states that it is meant to undo historical injustices meted out to forest dwelling population in not recognizing their rights to land and resources. It also asserts that the rights to these communities include responsibilities for the sustainable use of forests and conservation of biodiversity.

The Forest Rights Act-2006 recognizes that sustainable use of forest resources by tribals is helpful in conservation of biodiversity. In fact, this was proved during forests were under community ownership in pre-British period. But the Forest Department should keep its vigil on maintenance of forests by tribals. Timber merchants, poachers, smugglers and market forces should not enter the forest under the cover of tribals and Forest Rights Act-2006.

\section{References}

1. Archana Prasad, Environmentalism and the Left, Leftword Books, New Delhi, 2004.

2. Vandana Shiva, Ecology and the Politics of Survival, Sage Publications, New Delhi, 1991. 3. G.S.Halappa, History of Freedom Movement in Karnataka, Vol II, Bangalore, Government of
Mysore, 1969.

4. Karnataka State Gazetteer, Uttara Kannada district, Bangalore, Government of Karnataka. 5. Pandurang Hegde, Chipko and Appiko: how the people save the trees, Quaker Peace and
Service, January 1988. 6. Pandurang Hegde, Chipko Becomes Appiko in Karnataka, Parisara Samrakshana Kendra,
Sirsi, Uttara Kannada district, 1985. 7. K.Prabhakar Achar and Vidya Nayak, Dakshina Kannada Devara Kadugalu, Nagarika Seva
Trust, Guruvayanakere, Dakshina Kannada district, 2006.

8. T.N.Prakash, Peaceful Soultions for Problems in Malenadu, Samajavadi Adhyayana Kendra,
Bangalore, 2005 .

9. Nisarga Sandesha (Weekly), Dakshina Kannada Zilla Parisarasktara Okkoota, Guruvayanakere, Dakshina Kannada District, May 28, 1999. 
10. Hand Bills: Nagarika Seva Trust, Guruvayanakere, Dakshina Kannada District, Karnataka. May 1999.

11. Hand Bills: Kudremukh Rastriya Udyana Virodhi Okkoota, Karnataka, February 2004.

12. Venkitesh Ramakrishnan, Hope and Fear of Forest Rights Act, Frontline, February 29,2008.

13. The Times of India, October 30,1986.

14. Deccan Herald, March 4,2005. 